\title{
Variability of News Interpretation in Political Discourse (A Case Study of the Internet Materials Covering the 2014 and 2018 Winter Olympic Games)
}

\author{
Nikolay D. Golev, Lidiya G. Kim and Irina V. Saveleva* \\ Kemerovo State University \\ Kemerovo, Russian Federation
}

Received 14.09.2020, received in revised form 31.01.2021, accepted 17.03.2021

\begin{abstract}
This paper focuses on the analysis of the discourse formed by the ordinary citizens discussing news on the Internet social networks. Conceptualizing the theory of the variability of interpretation, the authors study political discourse emerging on Runet, with the aim of identifying the determinants of variation. The empirical base is the news published on "Newsland.com", which covers the 2014 and 2018 Olympic Games. These mediated events do not aim to focus on political issues. However, they stimulate the interpretation activity of the addressees who tend to discuss political background of the sports events as well as to disclose major problems in society. As the analysis shows, there are two groups of factors influencing the interpretation activity of the participants of political discussions on the Russian Internet: objective, determined by the text as a sign, and subjective, determined by the interpreter's attitude towards the mediated event. The authors argue that the semantic and pragmatic presumptions, as well as the implicatures of the media news are among the mechanisms of interpretative variation. Additionally, the paper shows a significant role in the interpretation of such a subjective category as anticipation or expectation, which also refers to the implicatures. This factor largely determines the interpreter's point of view on the information presented in the article. The methodological pathos of the article is to assert the possibility of identifying, describing and modeling internal and deep categories of everyday political discourse based on the analysis of its external manifestations.
\end{abstract}

Keywords: interpretivism, internet commentary, semantic block, semantic zone, source text, political worldview.

The research is supported by the RFBR grant (project No. 19-012-002 "Everyday political communication in social networks: a comprehensive linguistic analysis").

Research area: philology.

\footnotetext{
(C) Siberian Federal University. All rights reserved

* Corresponding author E-mail address: ngolevd@mail.ru, kimli09@mail.ru, saviren1973@mail.ru ORCID: 0000-0003-4437-8489 (Saveleva)
} 
Citation: Golev, N.D., Kim, L.G., Saveleva, I.V. (2021). Variability of news interpretation in political discourse (a case study of the Internet materials covering the 2014 and 2018 Winter Olympic Games). J. Sib. Fed. Univ. Humanit. Soc. Sci., 14(4), 568-583. DOI: 10.17516/1997-1370-0743.

\title{
Вариативность интерпретации в политическом дискурсе (на материале интернет-комментариев к статьям о зимних Олимпийских играх 2014 и 2018 гг.)
}

\author{
Н.Г. Голев, Л.Г. Ким, И.В. Савельева \\ Кемеровский государственный университет \\ Российская Федерация, Кемерово
}

\begin{abstract}
Аннотация. Данная статья посвящена коммуникативно-дискурсивному анализу дискурса, образуемого обсуждением политических событий рядовыми гражданами в социальных сетях Рунета. Основной аспект анализа лингвоинтерпретационный. В статье устанавливаются две группы факторов, влияющих на интерпретационную деятельность участников политических дискуссий в русском интернете: 1) объективные, текстовые, определяемые содержанием обсуждаемой статьи; 2) субъективные, дотекстовые, определяемые отношением интерпретатора к описываемому в интернетпубликации событию и его мировоззренческими установками. На основе анализа лингвистической и экстралингвистической составляющих интерпретирующих суждений, а также сопоставления плана содержания и плана выражения интерпретируемого текста осуществлено моделирование имплицитной картины мира индивидуальных и групповых участников интернет-дискуссий. Доказана значимая роль в интерпретационной деятельности такой субъективной категории, как предвосхищение, которая относится к дотекстовым факторам и в существенной мере детерминирует точку зрения интерпретатора на излагаемую в статье информацию. Авторы статьи предполагают, что данная категория формирует определенные стереотипы интерпретации, некоторые из них имеют ментально-психологический, социально-групповой, а в ряде случаев и национальный колорит. Методологический пафос статьи заключается в утверждении возможности выявления, описания и моделирования внутренних и глубинных категорий обыденного политического дискурса на основе анализа его внешних, поверхностных проявлений.
\end{abstract}

Ключевые слова: интерпретивизм, интернет-комментарий, семантический блок, смысловая зона, текст-источник, политическая картина мира.

Статья выполнена при поддержке гранта РФФИ (проект № 19-012-00202 «Обыденная политическая коммуникация в социальных сетях: комплексный лингвистический анализ»).

Научная специальность: 10.00 .00 - филологические науки. 


\section{Introduction}

The public availability of online resources, including political discussions, not only broadens the understanding of political communication, but also promotes the study of the impact of public opinion on politics (Davis, 2005; Kushin, 2009; Wright, 2012). As Page et al. notes, online environment has penetrated into and merged with everyday interpersonal communication, and is "still distributed across potentially large-scale audiences" (Page et al., 2014).

In this regard, today the focal point of different sciences is non-professional political communication. Originating in various areas of everyday communication, "online political talk" also attracts the attention of researchers interested in linguistic ways of expressing political views (Kim et al., 2013). In the 1990s, the object of political linguistics and discourse analysis was mainly the official government websites or pages created by the political elite (Chudinov, 2008; Hill \& Hughes, 1998). However, at the beginning of the millennium the research focus shifted to the discourse of electronic media, including not only news pages, but also "comment threads" (space for comments), in which any user can leave a response, including evaluation of political events (Canter, 2012; Graham et al., 2017; Misnikov et al., 2016; Speakman, 2015).

In many researches focused on linguistic analysis of political discourse it is noted that there is a need for in-depth study of those platforms for discussions where policy issues are intertwined with everyday ones (Dijk, 2008; Habermas, 1989; Wodak, 2011). The pages of news publications provide an opportunity for ordinary citizens to interpret political events in the form of comments. As a result of the perception of texts on political topics, the addressees of political Internet discourse become addressers. Hence, their political intentions are directly represented in language and discourse (Golev, 2011).

However, everyday (non-professional) political discourse is also born in the Internet spaces intended, for example, to discuss films and TV series, sports events, etc. Interestingly, today the public are increasingly discussing the issues of social welfare, patriotism, freedom, and equality in the comments to the events from different spheres of social life.

The search for the common ground of everyday political consciousness with a professional one (both official and opposition) using the material of the non-professional discourse is a significant task of everyday political linguistics, which is not yet formulated sufficiently clearly and precisely as a scientific problem. The subject of everyday political linguistics is the linguistic means of expressing those concepts, existing in the ordinary citizens' minds, which influence the formation of ideology and political worldview (Bennett, 2012; Golev, 2011; Popkova, 2014). Insufficient study of non-professional political discourse, which is formed in the comments to the materials of non-political orientation, gives relevance to the problem under study.

The study of comments to non-political events from the perspective of the variative-and-interpretative functioning of the text makes it possible to identify the underlying text-generating mechanisms. Description of verbal means of manifestation of ordinary consciousness in the paradigm of linguistic interpretivism allows taking into account the specificity of relations between the addressee, the author, and the text. Along with this, it also makes it possible to include pre-text and implicit components of everyday interpretation in the analysis (Golev \& Kim, 2014). Additionally, the researchers focus on the "reconstruction of the author's mental world", immersed in certain conditions during the text creation (Dem'iankov, 1989).

Thus, the aim of this study is to identify the specific features of everyday political discourse, which is produced as an outcome of the interpretative activity of the recipient of non-political events, and to describe the relationship of the author of the text and its recipients, which is formed on the basis of the interpreting activities of the latter.

The results of the analysis make it possible to identify the main vectors of interpretation, including implicit and explicit meanings of the original non-political text. As the analysis shows, the discussion of sporting events cer- 
tainly touches on political topics, regardless of the presence of political meanings in the propositions of the source text. However, the structural and substantive features of the interpreted discourse have a significant impact on the formation of the field of interpreting texts. This interdependence is determined by the implicit meaning of the discourse as a space coherently formed by the multi-interpretational potential of its constituents.

\section{Theoretical Framework}

\section{Linguistic Interpretivism}

Written and oral process of thinking, language and speech functioning is manifested in the multifaceted nature of text communication. This study is based on the theory of variative-interpretative functioning of the text. The research methodology is determined by the approach outlined by V.Z. Dem'iankov as linguistic interpretivism developed within the framework of the Kemerovo scientific school "Social and cognitive functioning of the Russian language".

The interpretive approach has been developed in line with the cognitive-discursive paradigm of Russian linguistics since the end of the $20^{\text {th }}$ century. From the point of view of interpretivists, the interpreter infers the meaning of a word as it is not embedded in a language form. Accordingly, interpretation is understood as a cognitive process and at the same time the result in establishing the meaning of speech and/ or non-speech actions. V.Z. Dem'iankov, largely following the premises of logical-philosophical, semantic and pragmatic theories, identifies the following prerequisites of this approach:

1. Interpretation is simultaneously seen as a process, a result, and a recipient's mindset. The result can be perceived both externally and internally as understanding.

2. Interpretation is a purposeful cognitive activity that has feedback from the local and global goals of the interpreter, who is not always sure of the purposefulness of the actions of the author of the perceived speech.

3. Interpretation consists in establishing and/or maintaining harmony in the interpreter's mental world, which can be expressed in the awareness of the properties of the context of speech and in placing the results of such awareness in the space of the interpreter's inner world.

4. The object is interpreted only within the framework of the system, when a set of acceptable types and forms of presenting the result is defined in advance. According to the expression, in particular, the genesis, social and personal motives of the author are restored.

5. Meanings do not form a separate world, but appear only as a result of successful interpretation. Interpretation is an attempt to create a value according to some goals, for which specific strategies are used. It is the interpreter's mind, in which the meaning acquires its verbal form widening or narrowing, or even essentially reshaping the interpreter's inner world.

Speech value statement harmonizes with the preceding context. The meaning of the expression is the actualized speech meaning within the framework of the momentary situation of interpretation (Dem'iankov, 2004).

\section{Text as a Result of Variative- and-Interpretative Process}

According to the concept developed in the study, the text in the system-centric dimension is a "bundle" of potential meanings (Kim, 2013). Their implementation takes place in the course of its perception by the reader, i.e. in the process of the interpretative functioning of the text in the addressee's mind Therefore, the result of this activity is the interpreting text, the content of which is caused, among other factors, by the implementation of the implicit meanings of the original, interpreted text.

At the same time, we take into account the phenomenon of variability being a key property of language (Golev \& Kim, 2009). The system of language and its elements are inevitably variable both in terms of the signified and in terms of the signifier, since language has a large but finite set of means for expressing an infinite set of meanings. Hence, it gives the subject of speech a certain freedom to establish the connection between sign and meaning.

As the factors of variability of text interpretation are concerned, they fall into two groups: objective, text-centered (the factor of the text) and subjective, anthropocentric (the 
factor of the addressee-interpreter). Notably, we assume that the addressee is an active and creative participant in the perception of the text language activities aimed at the interpretation of its semantic content. Following the phenomenological conception, we regard interpretation as cognitive activity. This activity involves "obtaining on the basis of one, "initial" - interpreted - object of another object, different from it and proposed by the interpreter as equivalent to the initial on a specific background of situations, a set of presumptions and knowledge" (Dem'iankov, 1982: 327).

\section{Implicit and Explicit Meanings of the Text}

As it is universally acknowledged, almost any statement contains implicit information additionally to its explicit layer (Implitsitnost' v iazyke i rechi, 1999; Paducheva, 2004; Strawson, 1964; Yus, 1999). As I.V. Arnol'd notes, an important feature of implicit information is that it has a variable interpretation. In linguistic semantics there are several types of implicit information in a statement, of which the most important for us are semantic and pragmatic presupposition and implication (consequence) (Arnol'd, 1982).

Semantic presupposition is understood as an implied semantic component of a sentence, which is not expressed in it with sufficient explicitness. Each presumption is "generated" by an element (a word or syntactic construction) of the sentence, i.e. included in the description of its meaning (Asher \& Lascarides, 1998; Dynel \& Cap, 2017).

E.V. Paducheva distinguishes, on the one hand, existential and factual presumptions, and, on the other hand, presumptions in the interpretation of words (Paducheva, 2004). At the same time, one sentence can correspond to several presumptions that actualize its different semantic components. The implicit components also include a pragmatic presupposition, i.e. the presumption of the listener's knowledge. "The pragmatic presumption is pragmatic in the sense that the characteristic of its content includes a reference to the speaker, i.e. to one of the pragmatic components of the speech act" (Paducheva, 2004: 124). The component of the Common Ground Condition of the speaker and listener is a pragmatic presumption (Qualif, 2017).

The study of the implicit information contained in the news, however influencing the development of the interpretative process and determining the meaning variations proposes the question about the sources of this information. Primarily, we take into consideration the Maxim of Quantity, saying "Give only the necessary amount of information - not too much or too little" and the associated postulate of the method (be brief, avoid unnecessary verbosity) (Grice, 1991; Stalnaker, 1985).

The implementation of these postulates in text organization provides the inclusion of implicit components in the structure of the text, the need for which is confirmed by the general communicative principle of least effort in speech. The speaker does not verbalize information in full, but concentrates language resources in the field of relevant information. Another related to the named source of implicit information is the specificity of the receptive process, which consists in the text form semantization as a procedure of meaning-making. Extracting the information, the recipient embeds it in his picture of the world while completing the missing semantic links. The result of this factor, which determines the process of interpretation, may be the phenomenon of "conflict of interpretations", implying the presence of polar points of view on the same issue (Ricoeur, 1998).

\section{Everyday Political Linguistics as a New Field of Study}

Today a number of sciences exploring a naive discourse have formed a new direction, synthesizing the achievements of political linguistics and the theory of everyday knowledge, everyday political linguistics. Ordinary political linguistics is closely connected with the political linguistics, which explores political communication, i.e. speech activity that focuses on the promotion of certain ideas, the emotional impact on citizens, and their motivation to political action (Golev, 2011; Golev \& Kim, 2014; Saveleva, 2015; Tan et al., 2007).

While political linguistics focuses on the use of political discourse, the language of pol- 
itics for the purpose of exercising power, everyday linguistics focuses on the description of the socio-cognitive functioning of non-professional political discourse, on the knowledge that ordinary native speakers exchange when discussing political issues. Ordinary political linguistics is also aimed at studying the peculiarities of everyday language consciousness on the material of political texts and fragments of the citizens' language system.

\section{Methods and Materials}

The communicative-discursive approach presented in this paper focuses on the phenomenological and linguistic value of everyday interpretation of political events by Russian Internet users. The main method of modeling the interpretation activity of ordinary participants of the Internet discussions on political topics is an in-depth linguistic (semiotic) analysis of interpreted and interpreting discourses implemented within communicative approach to discourse analysis.

The first stage involves the identification of semantic blocks objectified in the text under discussion by the method of semiotic analysis. The second stage entails the identification of semantic zones of the original (interpreted text), actualized by the authors of the comments. To achieve this the authors apply the "addresser - addressee" conception to discourse analysis. At the third stage, a bundle of interpretations (semantic versions) of the source text is revealed. They are further classified on various grounds in order to describe the most frequent discourse structures, thus allowing the researchers to uncover the mechanisms of the addressee's interpretative activity. This stage results in establishing the semiotic means of the political worldview representation in the interpretation of non-political events.

The empirical data elicited for the analysis are online commentaries posted by native Russian speakers on www.Newsland.com. Internet comments have been the focal point of linguistic, political and discourse researches for the last two decades. Comments of ordinary citizens are of interest for interpretative linguistics, as their generation is the result of active (interpreting) activity of the addressee, considered as an active participant of communication. In addition, the comments to the media news explicate the dynamic changes taking place in the society as a whole and in the political consciousness of its individual representatives, in particular (Golev, 2011; Reader, 2012; Saveleva, 2015; Shanahan, 2017; Wojcieszak \& Mutz, 2009).

To illustrate the developed conception we used the reports of two Olympic Games: the Winter Olympic Games-2014 in Sochi, Russia, and the Winter Olympic Games-2018 in Pyeongchang, South Korea. These events have attracted great attention of the world's audience as well as of the Russian viewership, having received quite a number of controversial opinions. The choice of the data for the analysis is caused by the observed tendency to have an extensive interpretation aptitude in regards to major sports events and their political overtones. The grand sports events such as the Olympic Games are always set on the media agenda. Reasonably enough, they stimulate the citizens' discussions and become politicized. Interiorization of such phenomena occurs through the perception of the competition itself and through the discursive interpretation of the latter. Therefore, the coverage and the discussion of news from South Korean Pyeongchang caused hot debate that acquired its political connotation due to the fact that the Russian team could not participate under its own flag. The connection between these two events and the current political environment is obvious. So, the analysis of the Internet comments to the coverage of the Olympic Games, held at a fouryear interval, seems to be of particular interest in terms of identifying common and different tendencies in the interpretation activity of the public.

\section{Results}

The development of the meanings of the source text in the addressee's mind allows us to observe the asymmetric vectors of perception of the primary text and the generation of the secondary one. Basing on the example of news discourses devoted to the events of the Olympic Games-2014 in Sochi and the Olympic Games-2018 in Pyeongchang, we will 
present practical outcomes that would contribute to the theory of interpretative functioning of the text.

The first news source is the news headlined "Closing Olympic Ceremony designed in Art-House Style" that was published on $w w w$. Newsland.com in February 2014. It is likely to reveal its multi-interpretation potential due to its relatively transparent content and the author's intention. However, the preliminary analysis showed that quite a substantial number of political views and opinions emerge in the comment thread.

The news text contains the blocks of both explicit and implicit information that implement dictum and modus meanings (propositions and intentions). Dictum meanings receive verbalization in the form of the explicitly expressed information, forming the dictum blocks of the interpreted (source) text. Modus meanings are presented implicitly. Our semiotic analysis of the explicit components of the text allows us to distinguish several semantic blocks (hereinafter $-\mathrm{SB}$ ):

1. The Olympics are over. This semantic block (SB 1) has been distinguished on the basis of the explicit units of the text, forming a single semantic space and working on the central idea of "closing ceremony". Closing is associated with the final point of the event, with its final stage. Accordingly, the idea of completing and closing the Olympics is actualized in the following statements:

The first ever white Olympics in Russia lasted 17 days, during which 98 sets of medals were played. The closing ceremony of the Olympic Games will be held in the Art-house style; Sochi's Fisht stadium is preparing for the closing ceremony of the XXII winter Olympic Games (Newsland.com. February 2014. Closing Olympic Ceremony designed in Art-House Style). The narrative style of the first statement outlines the spatial dimension of the text, supported by quantitative indicators. The key expression closing ceremony, repeatedly introduced in the article, also conveys the semantics of completion.

2. The Russian Team became the leader in the number of medals. This semantic block (SB 2) has been allocated by the research- ers on the basis of the following chunks of the news:

The Russian national team became the winner of the unofficial team standings, becoming the leader in both gold and total number of medals. Our team finished the performance in Sochi, winning a total of 33 medals: 13 gold, 11 silver and 9 bronze (Newsland.com. February 2014. Closing Olympic Ceremony designed in Art-House Style).

The synonymous series formed by the lexemes leader and winner, as well as the use of the generalizing adjective total contribute to the formation of SB 2. Despite the fact that the commented news is underrepresented in the interpreted discourse, placing these units in a strong position brings it into the focus of perception.

3. The semantic concept of the closing ceremony is the idea of spring and rebirth. This semantic block actualizes the general concept of the ceremony and is formed in the following fragment:

According to the creative Director of the ceremony, one of the main reasons for involving the children's choir in the ceremony is to show the idea of spring and rebirth. Although the ceremony will be imbued with light sadness, but in less than a few days spring will come, and spring and children are a message about the future, which comes despite the end of the holiday of Games (Newsland.com. February 2014. Closing Olympic Ceremony designed in Art-House Style).

On the one hand, the representative of the show's tone is the sublime literary expression of light sadness and, on the other, the parallel theme of spring - to show the idea of spring and rebirth - actualizes the inherent contradiction of the Russian soul (to be sad and happy at the same time). In addition, the message about the future conveys the idea of continuity in the Olympic Games.

The distinguished semantic blocks reflect the dictum meanings of the source text, which are modified in the commenters' postings, forming the corresponding semantic zones. At the same time, if the source text carries rather neutral mood, the participants' interpretative statements in the discussion have a pronounced 
emotional tone. For example, in the comments to SB 1 we notice the interpretation with a comparative aspect, accompanied by a negative connotation:

The Olympics, let us say, damn lost - 33\% of the medals, compared to $63 \%$ in 1988 in Calgary... (Newsland.com. February 2014. Closing Olympic Ceremony designed in Art-House Style).

This commentary also interprets SB 2, giving a criticizing overview of the sportsmen's endeavors. Interestingly, we recognize the interpretation of SB 3 in the comments containing an ironic modus, hinting at borrowing both the term and the concept, through the introduction of the pun house-chaos and the author's humorous prediction:

The closing ceremony of the Olympics will be held in the style of art CHAOS - - - so the Olympics would be remembered for a long time! (Newsland.com. February 2014. Closing Olympic Ceremony designed in Art-House Style).

Thus, we have identified three implicit semantic zones (SZ), the first of which is a semantic presupposition, since its content is determined by the semantics of the lexical units that make up the text.

1. The closing ceremony of the Olympics is a grand spectacle. This semantic zone has been formed as a result of the text cohesive property, allocated at the level of explicit meanings. Thus, the key word ceremony contains the denotative seme celebration and is defined as "a formal religious or public occasion, especially one celebrating a particular event, achievement, or anniversary" (Newsland.com. February 2014. Closing Olympic Ceremony designed in Art-House Style). The lexeme ceremony repeatedly used in the news contributes to the formation of SZ 1 in the interpreted news:

Among the stars who will take part in the ceremony; the Director of the closing ceremony was an Italian theater Director; the ceremony will be attended by a children's choir of 1 thousand people; the ceremony of handing over the Olympic flag (Newsland.com. February 2014. Closing Olympic Ceremony designed in Art-House Style).
Additionally, the implicit text units convey the idea that "the closing ceremony is a grand spectacle" and incorporate the semantic interpretative vector "the scale of the event - the greatness of the state and its leader". This type of implication is seen as a semantic presupposition. The semantic zone "the closing Ceremony of the Olympics is a grand spectacle" is represented in the following Internet comments:

(1) The Whole world is glued to the TV and is watching the miracle of the closing of the super Olympics!!! (Newsland.com. February 2014. Closing Olympic Ceremony designed in Art-House Style).

(2) It was certainly spectacular (Newsland. com. February 2014. Closing Olympic Ceremony designed in Art-House Style).

In the first commentary, the reader focuses on the idea of the event as attracting a global audience. It coincides with the commenter's emotions, expressed by means of the emotional words, such as miracle and super. The author of the second response uses the adjective spectacular, which conveys the concept of greatness.

The remaining implicit layers of information are pragmatic presuppositions or implicatures, since these meanings are not verbalized directly in the commented news; they are caused, on the one hand, by the addressee's prior knowledge and, on the other hand, represent a logical inference that is presented explicitly.

2. The Olympics united the country. This semantic zone is formed on the basis of the following explicit components of the source article:

The First ever white Olympics in Russia; the Russian national Team won the unofficial team competition; Our team completed the performance in Sochi; the closing Ceremony will be dedicated to Russian culture; ... the audience will see again; ...the ceremony will be attended by a children's choir of 1 thousand people, which was assembled from all 83 regions of Russia (Newsland.com. February 2014. Closing Olympic Ceremony designed in Art-House Style).

First of all, the idea of unification is translated through the collective nouns denoting 
a group of people united by one occupation, which were used in the interpreted text: the national team, the team, the choir, the audience. These units are supported by some linguistic units denoting the spatial features of the country, both its larger fragments and smaller ones: the territory of Russia, 83 regions of Russia, Sochi. Such explicit units of the text as the territory of Russia, the Russian national team, our team, Russian culture and some others actualize the idea of unification. This semantic information is a pragmatic presupposition, i.e. the knowledge that the Olympics as an important global event, broadcast by the media, attract the attention of the global viewership. The desire to win unites the Russia's team fans. Therefore, the Olympiad unites the whole country. SZ 2 is represented in the following Internet comments:

(1) And the Olympics united all of us! (Merriam Webster's Online Dictionary).

(2) The whole country is sitting at the TV and rejoices in the victory of Russia in the super Olympics! (Newsland.com. February 2014. Closing Olympic Ceremony designed in ArtHouse Style).

As you can see, like the author of the news, the interpreter verbalizes the concept of unification (mostly virtual) through the same key concepts, thus, strengthening it with the metonymy the whole country is sitting at the TV.

3. Russia is a great country. This semantic zone has been formed by the following explicit components of the source text:

The Russian team became the winner of the unofficial team standings, becoming the leader in both gold and total number of medals; Our team finished the performance in Sochi, winning a total of 33 medals: 13 gold, 11 silver and 9 bronze (Newsland.com. February 2014. Closing Olympic Ceremony designed in Art-House Style).

Some lexical units, such as winner, leader, win, and similar predicates characterizing the Russian Olympic team express the explicit information relating to their victory. The strength and success of a sports team is projected on the strength of the country it represents. Therefore, the implicit information about the greatness of Russia is a logical consequence of the explicit information about the strong sports team of the country. The following Internet comments constitute this semantic zone (SZ 3):

(1) Now people have something to rejoice and be proud of (Newsland.com. February 2014. Closing Olympic Ceremony designed in Art-House Style).

(2) and everyone would like to live in such a great country as Russia - a great space, nuclear and sports superpower!!!!!!!!!!!!! (Newsland.com. February 2014. Closing Olympic Ceremony designed in Art-House Style).

(3) Russia has given mankind a miracle!!! So same as has presented and space!!! By paving the way for humanity there!!! (Newsland. com. February 2014. Closing Olympic Ceremony designed in Art-House Style).

Clearly, the feeling of joy and pride experienced by the author of the cited replies and manifested in the text-interpretant with the help of the predicative elements, is caused by an event of the world scale and the reflection on the greatness of the country, emotionally characterized as a superpower. This token contains a double hyperbola: the first is confined in the meaning of the token power (a large and powerful country), the second - in the prefix super-. The metaphorical use of the toponym Russia also contributes to the actualization of SZ 3.

4. President Vladimir Putin is a strong leader of a powerful state. Let us pay attention to the crystallization of the meanings that form this SZ. Obviously, the sources of the formation of this semantic zone are the following explicit components of the news:

The Russian Team became the winner of the unofficial team standings, becoming the leader in both gold and the total number of medals; Our team finished its performance in Sochi, winning a total of 33 medals: 13 gold, 11 silver and 9 bronze (Newsland.com. February, 2014. Closing Olympic Ceremony designed in Art-House Style).

Together with that, this semantic zone is an implication of the news about the victory of Russia's Olympic team. A strong sports team, a winning team, is a direct consequence of a strong winning country. A strong country is a consequence of the strength of its leader, i.e. 
President Vladimir Putin. This semantic zone is actualized by the following comment:

(1) And our President VV Putin is just fine! Finally united all country in an iron fist, and now no enemies are threatening Russia!!! (Newsland.com. February, 2014. Closing Olympic Ceremony designed in Art-House Style).

In this commentary, there is a completion of the semantic vector that has been gradually developed in the interpreted news, explicated by the use of the conjunction and in the initial position. We understand that the author continues to extend the idea. The idea of interdependence of power of the country and its leader, the President, is an inference. We also observe the totalitarian discourse containing metaphorical expressions, which were typical for the communist propaganda no enemies are threatening Russia, to unite in an iron fist, which uncovers the commenter's political worldview.

The interpretation space of the comment thread contains not only the zone of positive assessments of objective information, but also the zone of negative views. The analysis of interpretive vectors shows the discussion elaborating towards the acceptance of the truth of propositions and implicatures as well as their fallacy. In this case, the commentators express their opposing views. Notably, the zone of negative evaluations is determined not so much by explicitly expressed blocks as by implicitly presented information organized in the interpretative space. At the same time, there is a line of increasing distancing from assessments of a particular event to assessments of the general situation in the country. The Olympics often serve only as an occasion for proper political statements, though in many cases, they have nothing to do with the sporting events. We see in this a clear tendency to politicize the consciousness of ordinary participants in Internet discussions, e.g.:

5. The oligarchs do not care about the people. Some interpreters perceive this publication as part of the pro-government discourse aimed at preserving power. Indicators of this implication can be found in the following comments:
(1) Well, if the oligarchs have united against the common people and nothing more..;

(2) Poverty is now;

(3) The Whole country unlike you vampires just think how to pay the bills, to dress and to give education to the children, how to carry the burden of the elderly and to bring you, bloody thief, to "zu hundert" (Newsland. com. February, 2014. Closing Olympic Ceremony designed in Art-House Style).

In the interpretive space, sports issues inevitably intertwine with economic and political ones. Besides, provocative statements fit into any interpretative meaning-making processes. As illustrated above, we see that pragmatic presuppositions (i.e., the addressee's knowledge about the funds normally spent on the large-scale events) are represented in the texts through negative assessments and deorativization of discourse.

6. The Ukrainian problem. As we can see, the zones of negative meanings develop as a pragmatic presupposition of the web-site www.newsland.com readers. They actualize the political vectors of interpretations, representing the recipients' political worldview and showing their common background knowledge:

There are Maidans in Kiev, revolution, but in Sochi Limpiyada Muti (Russian slang).

As clearly seen, the zones of negative modus meanings develop as a pragmatic presupposition of the participants of the readers' community. They actualize the political vectors of interpretations, thus representing the political picture of the world of the news recipients, at the same time showing common background knowledge and opposite political views.

Let us compare the development of interpretation axes within the same interpreting community and similar news material by presenting the analysis of the second news text. The news text "Olympics 2018: the countdown of Russian shame has started" published on Newsland.com in April 2018, in contrast to the neutral semantic organization of the first, contains a modus of negative attitude to the Russian Olympic team. First of all, it is embedded 
in the title. The semiotic analysis of this text allowed us to identify the following semantic blocks used by the authors of the comments as interpretative dominants:

1. Participation in the competition without a flag is a disgrace to Russia. In the source news article, the author's subjective position allows to distinguish this semantic block. It is laid down in the title "Olympics 2018: the countdown of Russian shame has started" (Newsland.com. February 2018. Olympic Games - 2018: The countdown of the Russian shame has started). Since the headline is one of the strong positions of the news discourse, this topic is developed in the comments, signaling the semantic presupposition:

(1) Count of Russian shame started earlier...for example, in the commercials 1993, when the government began to seize the Jew (Newsland.com. February 2018. Olympic Games - 2018: The countdown of the Russian shame has started).

(2) What a shame. Strictly according to the ORTHODOXY! Slapped cheek - SUBSTITUTE ANOTHER! Bless those who curse and hate you! (Newsland.com. February 2018. Olympic Games - 2018: The countdown of the Russian shame has started).

In fact, the phrase Russian shame became the incentive for the text production in a series of comments. However, interpretative configurations are utterly diverse, from diachronic to theological.

2. Olga Graf's statement is a proud thing to do. This semantic block corresponds to the following propositions of the original text:

Skater Olga Graf, with a high chance of one of the awards, refused the invitation received from Lausanne, thus supporting her teammates suspended from the Games (Newsland.com. February 2018. Olympic Games - 2018: The countdown of the Russian shame has started).

I hope that as a result justice nevertheless will triumph, - so Olga explained the decision. Making it clear that honor and pride is not an empty phrase for her (Newsland.com. February 2018. Olympic Games - 2018: The countdown of the Russian shame has started).
The narrative describing the athlete's refusal to participate in the Olympics forms the $\mathrm{SZ}$ in the series of propositions. However, they also introduce the interpretation of the author of the news, stylized under the literary stanza of the great Russian pride (Newsland.com. February 2018. Olympic Games - 2018: The countdown of the Russian shame has started).

In the comments, this block forms a semantic zone, which is accompanied by an explication of an ambiguous attitude to the athlete's statement. The described vector of interpretation is also due to semantic presumption, the result of perception of the meanings of such text units as refused an invitation, supported teammates; showed integrity; pride not an empty phrase? The following responses demonstrate the development of SZ 2:

(1) Among athletes, there was only one patriot of Russia - it is Olga Graf (Newsland. com. February 2018. Olympic Games - 2018: The countdown of the Russian shame has started).

(2) Olga Graf deserves her name. She is our honor and glory! (Newsland.com. February 2018. Olympic Games - 2018: The countdown of the Russian shame has started).

(3) Olga Grafis as duplicitous as everyone else from the sport. Such a heroine (Newsland. com. February 2018. Olympic Games - 2018: The countdown of the Russian shame has started).

In the cited examples, we observe a conflict of interpretations, since most of the comments express proponent opinions. Yet, some readers express opposing views.

In the comments, this block forms a semantic zone followed by an explication of the ambiguous relation to the sportswoman's statement. This vector of interpretation is caused by the semantic presupposition, the result of the perception of such lexical units as refused an invitation, supported by teammates; showed integrity; pride - not an empty phrase?

3. The problem of doping in sports. This burning issue has microdiscursive nature and increases in connection with the performance of each of the Games. The link between the two sports megaevents - the Sochi Olympics and the Pyeongchang Olympics - does not 
have a long time gap, since it was reduced by the doping scandal. So, in the comments this interpretive vector is actively stimulated by other factors having an extralinguistic nature, e.g.:

Sport of the highest achievements without doping can not exist for a long time! Look at how our spat athletes will "rake" gold in Korea without doping! And it would be necessary to raise such a howl at the world and ALL the ATHLETES of the WORLD to GET through security DOPE! (Newsland.com. February 2018. Olympic Games - 2018: The countdown of the Russian shame has started).

The mundane nature of the conversation about sports and politics influences the development of interpretative dominants. Therefore, the following four semantic blocks are due to both the implicatures of the original discourse (the specifics of the situation against which the 2018 Olympics are discussed, both political and individual) and the expectancy factor.

4. The President Vladimir Putin. The theme of power has a timeless character in the Russian everyday consciousness. In the discussion concerning the Olympics, the question of the effectiveness of the current government is raised justifiably, acquiring the following form:

(1) Putin - and his team: No mind, no truth, no power of this, no living idea. Oh boy... The Ukrainian posts Chet about Putin's rating... )))) Is already a joke!!! (Newsland. com. February 2018. Olympic Games - 2018: The countdown of the Russian shame has started).

(2) Bandera P slept - now the Slavs brothers, the Ukrainians are not brothers. In the Baltic States, Russians have long been clamped, deprived of citizenship. if you don't know their language. DID OUR DAD VOVA PROTECT RUSSIANS??? Of course NOT! (Newsland.com. February 2018. Olympic Games - 2018: The countdown of the Russian shame has started).

These comments explicate the interpretation induced by the provocative and conflicting behavior of the readers, who are not interested in commenting on the merits and violate the principles of communication. Nevertheless, these interpretative lines can be found on the present-day Runet.
5. The Ukrainian problem. The discussion of sports issues branches out in the interpretative and semantic space of the readership, dividing them into the nuclear part, most closely related to the source text, and the periphery. Among the supplementary topics is the Ukrainian question, explicated in the following comments:

(1) There are no Ukrainians in Kuban..., you somehow way separated part of Russians, from other Russians? (Newsland.com. February 2018. Olympic Games - 2018: The countdown of the Russian shame has started).

(2) Remember, the Ukrainians - it's only the residents of Ukradina (Newsland.com. February 2018. Olympic Games - 2018: The countdown of the Russian shame has started).

(3) It was not enough to divide a single people within the Russian Federation, we do not need such a Russophobic policy (Newsland. com. February 2018. Olympic Games - 2018: The countdown of the Russian shame has started).

As you can see, these comments have nothing to do with the main line of commenting, which is interconnected with the content of the source news. One should note that they arise on the periphery of the interpretive space that is deliberately voiced by the participants of the conversation, defending their political positions.

\section{Conclusion}

As a result of the three-stage semiotic analysis, the semantic blocks that make up the text at the external, explicit level were identified. Then, on the basis of the communicative-discursive analysis of the interpretive space of comments, semantic zones were defined. These zones cover the second level of the text created by the supplementary meanings of its constituent units, as well as by the phenomenon of the semantic presupposition. As the research shows, this level has been formed in texts-interpreters regardless of the presence of the political mode of news discourse about world sport and the Olympics. In addition, the analysis of comments reveals the presence of the third incentive with commenting-pragmatic presupposition, resulting in the formation of 
peripheral zones on the Internet venues, mainly having a political character. In the commentaries on politically neutral (News article 1) and highly political discourses (News article 2), there are similar topics that arise from the implications of discourse as well as from broader context: the political situation in the country and in the international arena. These are the questions of the power, the conflict driven by the separation of Ukraine, low standards of living, as well as unreasonably high level of oligarchs' income, with an age-old question of corruption of those, who are in power.

\section{Discussion}

Thus, the interpreted discourse in the process of its functioning in the addressee's consciousness forms a multi-vector interpretive space. Interpretative vectors of development of semantic blocks of the News article 1, which substantially correlate with it, are mainly due to the action of semantic presumption mechanisms. The development of sports as well as political topics in the space of the commentaries occurs due to multi-interpretation potential of news article. Intentional component of the commentaries is primarily constructed as synergy phenomenon. Nevertheless, the connection between the comments, for example, their skeptical nature, can be traced at the level of pragmatic presupposition, which is associated with the basic principles of communication and the addressee's goals. When comparing the ratio of semantic blocks of the two analyzed news with the semantic zones of comments, there is no positive correlation between the modus component of responses. The neutrality of News article 1 does not affect the predominance of negative or positive evaluations in the replies. Neither does the article on 2018 Winter Olympics carrying a clear negative and ironic tone. Yet, the implicatures of both articles determine the politicized nature of the discussion. Additionally, there is an influence of the context, general political situation in the country and in the world, as well as political events preceding the Olympic Games 2018. Commonly, the Olympics act as the only reason for the actual political statements, though in many cases they have nothing to do with the sporting events. In general, news interpretation space can be presented as the integrative construction with linguistic and extra linguistic determinants affecting the formation of semantic zones of the commenting texts (See Fig. 1).

The study of the text in the communicative aspect - from the standpoint of variability of interpretation - sheds light on its semantic organization, including explicit information and implicit content of the text. At the same time, these language data clearly demonstrate the interpreter's implicit intentions associated with the action of the mechanism of expectation. It turns out to act as the most important factor

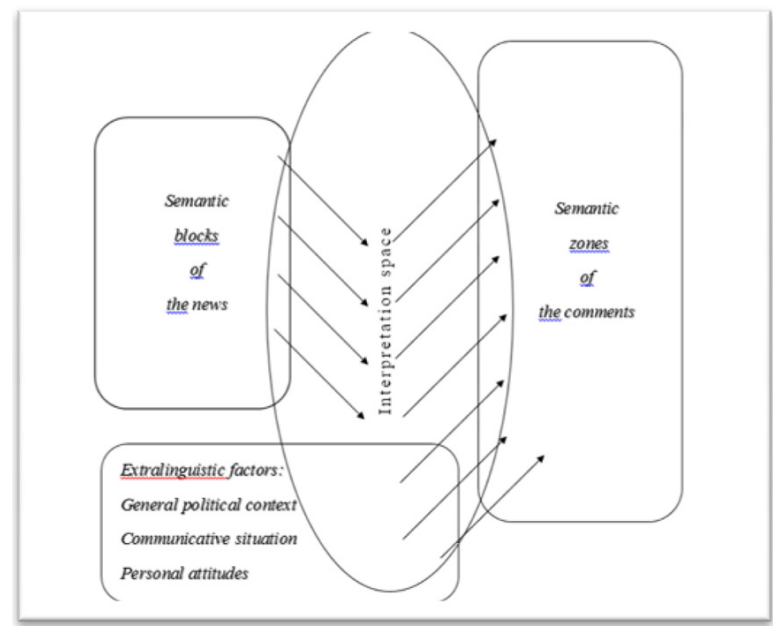

Fig. 1. The interpretative space of news article (compiled by the authors) 
of its receptive-interpretative activity. Actualization of the semantic components of the text is carried out in accordance with the pre-text settings of the addressee taking on the role of the reader-interpreter, their communicative intentions as well as their socio-political views. Such a dual determination allows to adequately describe the structure of the interpreting text (the thread of all comments) as a communicative whole, and in its perspective to structure the commented text in a new way: from the standpoint of perlocution. This position assumes structuring with repulsion not from what the author wanted to say (i.e. not from the illocution), but from what he said (i.e. what was perceived by the readers of this text).

The implications of the study include the possibility to model the internal intentions of the participants of ordinary political discussions and, in general, their political picture of the world by their external (speech) manifestations.

\section{References}

Arnol'd, I.V. (1982). Implikatsiia kak priem postroeniia teksta i predmet filologicheskogo izucheniia [Implication as a text-generating technique and the subject matter of philology]. In Voprosy iazykoznaniia [Issues in Linguistics], 4, 83-91.

Asher, N., Lascarides, A. (1998). The Semantics and Pragmatics of Presupposition. In Journal of Semantics, 15, 239-299.

Bennett, W.L. (2012). The personalization of politics: Political identity, social media, and changing patterns of participation. In Annals of the American Academy of Political and Social Science, 644 (1), 20-39. DOI: $10.1177 / 0002716212451428$

Canter, L. (2012). The misconception of online comment threads. Content and control on local newspaper websites. Available at: http://www.tandfonline.com/doi/abs/10.1080/17512786.2012.740172

Chudinov, A.P. (2008). Politicheskaia lingvistika: Uchebnoe posobie [Political linguistics: Student's book]. Moscow, $256 \mathrm{p}$.

Davis, R. (2005). Politics Online: Blogs, Chatrooms, and Discussion Groups in American Democracy. London: Routledge.

Dem'iyankov, V.Z. (1982). Konventsii, pravila i strategii obshcheniia (interpretiruiushchi podkhod k argumentatsii) [Conventions, rules and communication strategies (interpretive approach to reasoning). In The News of the Academy of Science of Soviet Union. Literature and Language, 41 (4), 327-337.

Dem'iankov, V.Z. (1989). Interpretatsiia, ponimanie i lingvisticheskie aspekty ikh modelirovaniia na 'EVM [Interpretation, understanding and linguistic aspects of their computer modeling]. Moscow, Moscow University, 172 p. Available at: http://www.infolex.ru/Int0.html (Accessed February 5, 2019).

Dem'jankov, V. (2004). On the Interpretive Approach to Dialogue Analysis. In IADA 2004 Chicago "Theoretical Approaches to Dialogue Analysis". March 30 - April 3, 2004. Chicago: Northeastern Illinois University, p. 15.

Dijk, van T.A. (2008). Discourse and Context. Cambridge University Press.

Dynel, M., Cap, P. (Eds.) (2017). Implicitness: From lexis to discourse. John Benjamins Publishing. DOI: $10.1075 /$ pbns. 276

Graham, T., Jackson, D., Broersma, M. (2017). The Personal in the Political on Twitter: Towards a Typology of Politicians' Personalized Tweeting Behaviours. DOI: 10.1007/978-3-319-61708-4_8

Golev, N.D. (2011). Obydennaia lingvopolitologiia: problemy i perspektivy (Language studies of everyday political talk: issues and research). Contemporary research in political linguistics. In International conference. Ekaterinburg. Available at: http://www.philology.ru/linguistics1/golev-11.htm (Accessed February 5,2019$)$.

Golev, N.D., Kim L.G. (2009). Variativno-interpretatsionnoe funktsionirovanie teksta (k voprosu o rasshirenii granits lingvisticheskoi variantologii) [Variable-interpretive operation of a text (to the question of expanding the boundaries of linguistic variation studies)]. In Cheliabinsk State University Bulletin. Philology, Fine Arts, 34 (165), 12-21. 
Golev, N.D., Kim, L.G. (2014). Obydennye politicheskie internet-kommentarii kak proyavlenie variativnosti interpretatsii (oppozitsii "eksplictsitnoe - implitsitnoe", "proiavlennoe - ozhidaemoe") [Ordinary political Internet comments as the various interpretation results]. In Implicit and explicit strategies in Eastern European political discourse. Ekaterinburg - Zurich, 47-70.

Grice, G.P. (1991). Studies in the Way of Words. Cambridge, MA, Harvard University Press.

Habermas, J. (1989). The structural transformation of the public sphere. Boston, MIT Press.

Hill, K., Hughes, J. (1998). Cyberpolitics: Citizen activism in the age of the Internet. Lanham, Rowman $\&$ Littlefield.

Kim, L.G. (2013). Variativno-interpretatsionnoe funktsionirovanie teksta [Variable interpretation of the text functioning]. Moscow, URSS.

Kim, L.G., Mustaioki, A. \& Pietiliainen, Iu. (2013). Vospriiatie modernizatsii russkimi studentami kak rezul'tat vliianiia obraza avtora na interpretatsiiu politicheskogo teksta [Perception of modernization by Russian students as a result of the influence of the author's image on the interpretation of the political text]. In Politicheskaya lingvistika [Political Linguistics], 4, 47-59.

Kushin, M. (2009). Getting political on social network sites: Exploring online political discourse on Facebook. In First Monday, 14, 11. DOI: https://doi.org/10.5210/fm.v14i11.2645

Implitsitnost' v iazyke i rechi [Implication in language and speech] (1999). Moscow, Iazyki russkoi kul'tury.

Merriam-Webster Online Dictionary. Available at: https://www.merriam-webster.com/ (Accessed February 5, 2019).

Misnikov, Iu.G., Filatova, O.G., Chugunov, A.V. (2016). 'Elektronnoe vzaimodeistvie vlasti i obshchestva: napravleniiya i metody issledovanii [Electronic interaction between government and society: perspectives and research methods]. In Saint Petersburg Teaching Institute scientific news. Humanities and social sciences, 1, 239, 52-58.

Paducheva, E.V. (2004). Vyskazyvanie i ego sootnesennost's deistvitel'nost'iu [Statement and its correlation with reality]. Moscow, Editorial URSS, 288 p.

Page, R., Barton, D., Unger, J., Zappavigna, M. (2014). Researching language and social media: A student guide. London, Routledge, 202 p. DOI: 10.4324/9781315771786

Popkova, A. (2014). Political Criticism from the Soviet Kitchen to the Russian Internet: A Comparative Analysis of Russian Media Coverage of the December 2011 Election Protests. In Journal of Communication Inquiry, 38(2), 95-112. DOI: 10.1177/0196859914523984.

Qualif, M. (2017). Presupposition: A Semantic or Pragmatic Phenomenon? In Arab World English Journal (AWEJ), 8, 3, 46-59.

Reader, B. (2012). Free Press vs. Free Speech? The Rhetoric of "Civility" in Regard to Anonymous Online Comments. In Journalism \& Mass Communication Quarterly, 89, 495-513. DOI: 10.1177/1077699012447923.

Ricoeur, P. (1998). Hermeneutics and the Human Sciences: Essays on Language, Action and Interpretation. Cambridge University Press.

Saveleva, I.V. (2015). Variativnost' strategii tekstovospriiatiia i tekstoporozhdeniia: lingvopersonologicheskii aspekt (na materiale tekstov politicheskikh internet-kommentariev) [The variability of text production and text generation strategies: linguistic personality approach (the study of political Internet commentary]. Kemerovo, $220 \mathrm{p}$.

Shanahan, M. (2017). Journalism, Online Comments, and the Future of Public Discourse. New York \& London, Routledge.

Speakman, B. (2015). Interactivity and Political Communication: New Media Tools and their Impact on Public Political Communication. Available at: https://www.ceeol.com/search/article-detail?id=496453 (Accessed February 5, 2019).

Stalnaker, R. (1985). Pragmatika [Pragmatics]. In Novoie v zarubezhnoi lingvistike. Lingvisticheskaiya pragmatika [News in foreign linguistics. Language Pragmatics], 16, 419-438.

Strawson, P.F. (1964). Intention and convention in speech acts. In Searle, J.R. (Ed). The philosophy of language. Oxford University Press, 23-38. 
Tan, K.W.P., Swee, D., Lim, C., Detenber, B.H. and Alsagoff, L. (2007). The Impact of Language Variety and Expertise on Perceptions of Online Political Discussions. In Journal of Computer-Mediated Communication, 13, 76-99. DOI: 10.1111/j.1083-6101.2007.00387.x

Wodak, R. (2011). Suppression of the Nazi past, coded languages, and discourses of silence: Applying the discourse-historical approach to post-war anti-semitism in Austria. In Political Languages in the age of extremes. Oxford University Press, London, 351-380.

Wojcieszak, M.., Mutz, D.C. (2009). Online Groups and Political Discourse: Do Online Discussion Spaces Facilitate Exposure to Political Disagreement? In Journal of Communication, 59, 1, 40-56. DOI: 10.1111/j.1460-2466.2008.01403.x

Wright, S. (2012). From “Third Place" to "Third Space": Everyday Political Talk in Non-Political Online Spaces. In Javnost - The Public, 19, 3, 5-20.

Yus, F. (1999). Misunderstandings and explicit/implicit communication. In Pragmatics, 9, 4, 487-517.

\section{List of sources}

Newsland.com. Tseremoniia zakrytiia Olimpiady proidet v stile art-haus [Closing Olympic Ceremony designed in Art-House Style]. Available at: http://newsland.com/news/detail/id/1327900/ (Accessed February 5, 2018).

Newsland.com. Olimpiada-2018: otshchet russkogo pozora poshel [Olympics-2018: Countdown of Russian shame has started]. Available at: https://newsland.com/user/4296757178/content/olimpiada-2018-otschet-russkogo-pozora-poshel/6203583 (Accessed February 5, 2019). 